\title{
Acid invertase localization in leaves of the fern Pteris deflexa Link
}

\author{
J.E. Sayago, ${ }^{1}$ R.M. Ordóñez, ${ }^{2}$ M.I. Isla ${ }^{2}$
}

${ }^{1}$ Cátedra de Botánica, ${ }^{2}$ Cátedra de Fitoquímica, Instituto de Estudios Vegetales "Dr. Antonio R.

Sampietro", Facultad de Bioquímica, Química y Farmacia, Universidad Nacional de Tucumán

INQUINOA-CONICET, Ayacucho 471 (4000) San Miguel de Tucumán, Tucumán, Argentina

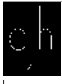

(C)2008 European Journal of Histochemistry

The localization of invertase, a key enzyme in plant carbohydrate metabolism, has been established in several higher plants, but there are no reports of it in ferns. The aim of the present work was to establish the localization of the previously reported acid invertase activity of Pteris deflexa in fronds tissues and to compare the findings with invertase localization in higher plants. Acid invertase, localized by immuno-histochemical and histochemical techniques on fresh tissues, was evident in vascular tissue, mainly in phloem. It was also detected in parenchymatic, sclerenchymatic and epidermic cells of petiole, rachis and rachis branches as well as in veins of leaf blades. Our results demonstrate that $P$. deflexa acid invertase localization is the same to that of higher plants. Hence, potential roles of the fern enzyme in relation to the storage and utilization of sucrose and to control carbon flux could be the same of those proposed to higher plants.

Key words: Pteris deflexa link, pteridaceae, $\beta$-D-fructofuranoside fructohydrolase, cellular localization, sucrose metabolism.

Correspondence: María Inés Isla,

Cátedra de Fitoquímica, Instituto de Estudios Vegetales, Facultad de Bioquímica, Química y Farmacia,

Universidad Nacional de Tucumán, Ayacucho 471

4000 - San Miguel de Tucumán, Argentina

Tel.: +54.381.4107220.

Fax: +54.381.4248169.

E-mail: misla@tucbbs.com.ar

Paper accepted on October 1, 2008

European Journal of Histochemistry 2008; vol. 52 issue 4 (October-December):255-262
S ucrose is the major end product of photosynthesis and the sugar transported over long distances in most higher plants. Before entering higher plant carbohydrate metabolism, this disaccharide must be cleaved into hexoses by invertase (E.C.3.2.1.26) or sucrose synthase (E.C.2.4.1.13). Invertase, the enzyme that catalyses the irreversible hydrolysis of sucrose into glucose and fructose, is present in several plant organs. It is generally accepted that there are three types of plant invertase: 1) acid insoluble invertase, ionically bound to the cell-wall; 2) acid-soluble invertase, localized in the vacuole; and 3) alkaline-soluble invertase, thought to be cytoplasmic (Tymowska-Lalanne and Kreis 1998). The subcellular localization of acid invertase, which differs between plants and organs (Benhamou et al. 1991, Frommer and Sonnewald 1995, Quick and Schaffer 1996), is considered to be directly related to the sucrose unloading pathway and mechanism (Patrick, 1997). Many physiological roles have been attributed to invertase isozymes and it seems that their functions depend on the organ, tissue or cells where they are expressed. A primary role of invertases is to supply carbohydrates to sink tissues. They also take part in sucrose partitioning between source and sink organs (Eschrich 1980, Sonnewald et al. 1991, Sturm et al. 1995, Cheng et al. 1996). Response to wounding and infection, control of cell differentiation and plant development, osmo-regulation and enlargement, and control of sugar composition in fruits and storage organs, are other proposed functions for higher plant invertases (Sturm and Tang 1999, Ordóñez et al. 2005).

Soluble acid invertase from Pteris deflexa fronds with an optimum $\mathrm{pH}$ of 5.0 is a glycoprotein that has a $\mathrm{Mr}$ of $90 \mathrm{kDa}$. It is composed of two subunits with Mrs of 66 and $30 \mathrm{kDa}$ (Sayago et al. 2001). $K_{m}$ values of the enzyme for sucrose, raffinose and stachyose are respectively 3.22, 10.8 and $38.5 \mathrm{mM}$ (Sayago et al. 2002). All these characteristics of 
the fern enzyme are closely related to those of acid invertases of higher plants (Tymowska-Lalanne and Kreis 1998, Sturm 1999).

Invertase activity localization has been established in some higher plant species (Krishnan et al. 1985, Wu et al. 1993, Kingston-Smith and Pollock 1996, Zhang et al. 2001, Sergeeva and Vreugdenhil 2002, Feshchenko et al. 2004, McLaughlin and Boyer 2004, Sergeeva et al. 2006). Since sporophytes of ferns are photoautotrophic vascular plants, it is reasonable to assume that the localization and functions of invertase activity are the same as those of higher plants. However, there is no information concerning its localization in fern and fern allies. Because of this, the aim of the present paper was to establish the acid invertase localization in $P$. deflexa fronds and to compare the results with the enzyme localization in higher plant tissues.

\section{Materials and Methods}

\section{Plant material}

Pteris deflexa Link is a terrestrial sporophyte with thick rhizomes, many adventitious roots and large fronds that consist of a petiole or stipe $(2 \mathrm{~m}$ long or more) which continues up through the expanded blade as the rachis ( $2 \mathrm{~m}$ long or more). The frond blade is threefold (basal segments) or twice (tip segments) pinnate. Uncultivated $P$. deflexa plants were collected in Horco Molle, Tucumán, Argentina. Voucher specimens have been deposited in the herbarium of Instituto de Estudios Vegetales, Facultad de Bioquímica, Química y Farmacia UNT.

\section{Enzyme extractions}

Soluble invertase from mature fronds of $P$. deflexa sporophytes was prepared as follows: fern tissue (100 g) was cut into small pieces and homogenized in $200 \mathrm{~mL}$ of $50 \mathrm{mM}$ sodium acetate buffer, pH 5.5, containing 1 mM 2-mercaptoethanol (buffer A). The homogenate was filtered through two layers of gauze and centrifuged at $21,000 \times \mathrm{g}$ for 15 minutes. The supernatant was designated as the soluble acid invertase fraction. The residual tissues from the soluble enzyme extraction was washed with buffer $A$ and centrifuged at 21,000 x $g$ until no acid invertase activity was detected and then was treated with buffer $\mathrm{A}$ added with $1 \mathrm{M}$
$\mathrm{NaCl}$ in order to extract invertase ionically bound to cell wall. This extraction was carried out at $4^{\circ} \mathrm{C}$ with shacking over night and the extract was then filtered and centrifuged as stated above. The supernatant was dialyzed against $10 \mathrm{mM}$ sodium acetate buffer pH 5.5 containing 1 mM 2-mercaptoethanol. The dialyzed supernatant was considered cell wall invertase.

\section{Enzyme assays}

Enzyme assays was performed according to Sayago et al. (2001).

\section{Anatomy studies}

Plant material was prepared according to Foster (1934). Samples were heated at $100^{\circ} \mathrm{C}$ for few minutes in distilled water containing drops of a nonionic detergent. Tissues were then treated with $3 \%$ sodium hydroxide at room temperature for two days. After washing, the samples were clarified with $50 \%$ sodium hypochlorite, washed with distilled water, conserved in $70 \%$ ethanol and stained with aqueous $1 \%$ tannic acid and $3 \% \mathrm{FeCl}_{3}$. The samples were mounted on slides in glycerin/water (50:50).

\section{Invertase histochemical determination}

Freehand cut slices of fresh petiole, rachis, rachis branches and lamina (sporophyll leaflets) were fixed in $4 \%$ formalin ( $\mathrm{pH} 7.0$ ) for 3 minutes at $4{ }^{\circ} \mathrm{C}$ and rinsed in distilled water at least 10 times during 1 hour in order to extract endogenous sugars. Thereafter, tissue sections were incubated at room temperature in $0.38 \mathrm{M}$ sodium phosphate buffer $\mathrm{pH}$ 6.0 , containing $0.96 \mathrm{mg} \cdot \mathrm{mL}^{-1}$ nitroblue tetrazolium, $0.56 \mathrm{mg} \cdot \mathrm{mL}^{-1}$ phenazine methosulfate, 25 units. $\mathrm{mL}^{-1}$ glucose oxidase and $100 \mathrm{mg} \cdot \mathrm{mL}^{-1}$ sucrose. Control slices, incubated without sucrose, and samples were rinsed in water and photographed under bright field light microscopy (Dahlqvist and Brun 1962).

\section{Antiserum productions}

For inmuno-histochemical assays the antibodies against acid soluble invertase from Solanum tuberosum have been prepared according to Isla et al. (1999). Briefly: rabbits were injected with the purified acid soluble invertase $(200 \mu \mathrm{g}$ of protein) emulsified in complete Freund's adjuvant. Five booster injections were given with invertase emulsified in incomplete adjuvant. Blood was collected 15 
days after the last injection. The antiserum was partially purified from the serum fraction by precipitation with solid $\left(\mathrm{NH}_{4}\right)_{2} \mathrm{SO}_{4}$ (40\% satn) and $\mathrm{DEAE}$ cellulose. The immunoglobulin-G fractions were collected and used in further experiments.

\section{Invertase immuno-histochemical determination}

Invertase immuno-localization was carried out on freehand cut slices of petiole, petiole branches and pinnae. Sections were washed with distilled water for 10 minutes. Tissue prints, obtained by a modification of the technique described by Kingston-Smith and Pollock (1996), were also used. Small pieces of frond tissues were included in $3 \%$ agarose; cross and longitudinal sections of different tissues were then printed on nitrocellulose membranes $(0.45 \mu \mathrm{m})$, previously soaked in $0.2 \mathrm{M}$ $\mathrm{CaCl}_{2}$ for 15 minutes and air dried. Total proteins were stained with amidoblack (1\% w/v) in 7\% acetic acid for 15 minutes. Membranes distaining was carried out with $7 \%$ acetic acid until a clear image was detectable. Invertase visualization was achieved by a specific antiserum: samples were incubated for 1 hour with 10\% (w/v) bovine serum albumin (BSA) in $20 \mathrm{mM}$ TRIS- $\mathrm{HCl}, \mathrm{pH} 7.4$, with $0.137 \mathrm{M} \mathrm{NaCl}$ (TBS) at room temperature with shaking. They were subsequently incubated with antibodies raised against acid soluble invertase from Solanum tuberosum diluted (1:1000) with TBS containing $5 \%(\mathrm{w} / \mathrm{v}) \mathrm{BSA}$, followed by washing and incubation $\left(30^{\circ} \mathrm{C}, 2 \mathrm{~h}\right)$ with anti-rabbit immunoglobulin conjugated with alkaline phosphatase (Sigma Immuno-chemicals). After washing, phosphatase activity was revealed by incubating the samples $\left(30^{\circ} \mathrm{C}, 15\right.$ minutes $)$ in $100 \mathrm{mM}$ Tris- $\mathrm{HCl}$ buffer $\mathrm{pH} 9.5$ containing $50 \mathrm{mg}^{-\mathrm{L}^{-1}} 5$ bromo-4-chloro-3-indolyl phosphate (BCIP), 340 $\mathrm{mg} . \mathrm{L}^{-1}$ nitroblue tetrazolium (NBT), $100 \mathrm{mM}$ $\mathrm{NaCl}$ and $50 \mathrm{mM} \mathrm{MgCl}$. A test were conducted with tissue slices and prints incubated with preimmune serum.

\section{Enzyme inmunoassay}

Specificity of the label patterns obtained with invertase antiserum was assayed by dot blotting as well as western-blotting.

Acid soluble invertase and cell wall invertase ( 3 $\mu \mathrm{g}$ of protein) were seeded on nitrocellulose membranes or subjected to SDS-PAGE (Laemmli, 1970) and transferred to nitrocellulose membrane (70 $\mathrm{V}$ for $2 \mathrm{~h}$ and then $90 \mathrm{~V}$ for $\mathrm{l} \mathrm{h}$ ). Each mem- brane was washed with $50 \mathrm{mM}$ Tris- $\mathrm{HCl}$ buffer $\mathrm{pH}$ 8 with $150 \mathrm{mM} \mathrm{NaCl}$ and $0.05 \%$ Tween 20 (TBST) supplemented with $2 \%$ fat-free milk pow$\operatorname{der}$ (Molico) for $2 \mathrm{~h}$ followed by thorough washings with $50 \mathrm{mM}$ Tris- $\mathrm{HCl}$ buffer $\mathrm{pH} 8$ with $150 \mathrm{mM}$ $\mathrm{NaCl}$ (TBS). Then, the membranes were incubated with $1 / 500$ diluted invertase antiserum in TBS for $\mathrm{l} \mathrm{h}$ and washed with TBS. Afterwards, they were incubated with anti-rabbit IgG-alkaline phosphatase conjugate (Sigma Immuno-chemicals) at room temperature for $\mathrm{l} \mathrm{h}$ and washed with TBST and TBS. Then, the membranes were stained with 5bromo-4-chloro-3-indolyl phosphate (BCIP) and nitro blue tetrazolium (NBT).

\section{Results}

\section{Anatomy studies}

Our observations of the anatomy of $P$. deflexa fronds petiole and rachis showed a vascular bundle as an inverted $\Omega$ shaped arc with ends that curved sharply outwards. The xylem consists of a large circular arc with some protoxylem at regular intervals (Figure $1 \mathrm{~A}$ ). Thinner stems like rachis branches possesses the same basic anatomical structure with minor differences in the vascular bundle form, where the xylem is $V$-shaped instead of the $\Omega$ shaped arc observed in thicker structures (Figure 1 $B$ ). The phloem is shaped by sieve tubes and parenchyma (Figure $1 \mathrm{C}$ ) and encloses the xylem concentrically (Figure $1 \mathrm{~A}$ ). The endodermis completely surrounds the vascular bundle on both the internal and external sides. A cortical parenchyma is observed between endodermis and mechanical tissue, which is represented by many layers of sclerenchyma cells (Figure $1 \mathrm{C}$ ). A simple layer of epidermic cells is observed in all structures.

\section{Invertase histochemical localization}

In the assayed conditions the tissue slices washing during one hour was enough to extract endogenous sugars. Control samples incubated without sucrose showed no acid invertase activity (Figure 2 A). The histochemical detection of total acid invertase activity (cell wall and soluble forms) in cross sections of rachis branches (Figure $2 \mathrm{~B}$ ) and longitudinal sections of petioles (Figure $2 \mathrm{C}$ ) showed the enzyme in vascular bundles (Figure $2 \mathrm{~B}$ and $\mathrm{C}$ ) and in cells of cortical parenchyma, mechanical and protection tissues (Figure $2 \mathrm{~B}$ ). 


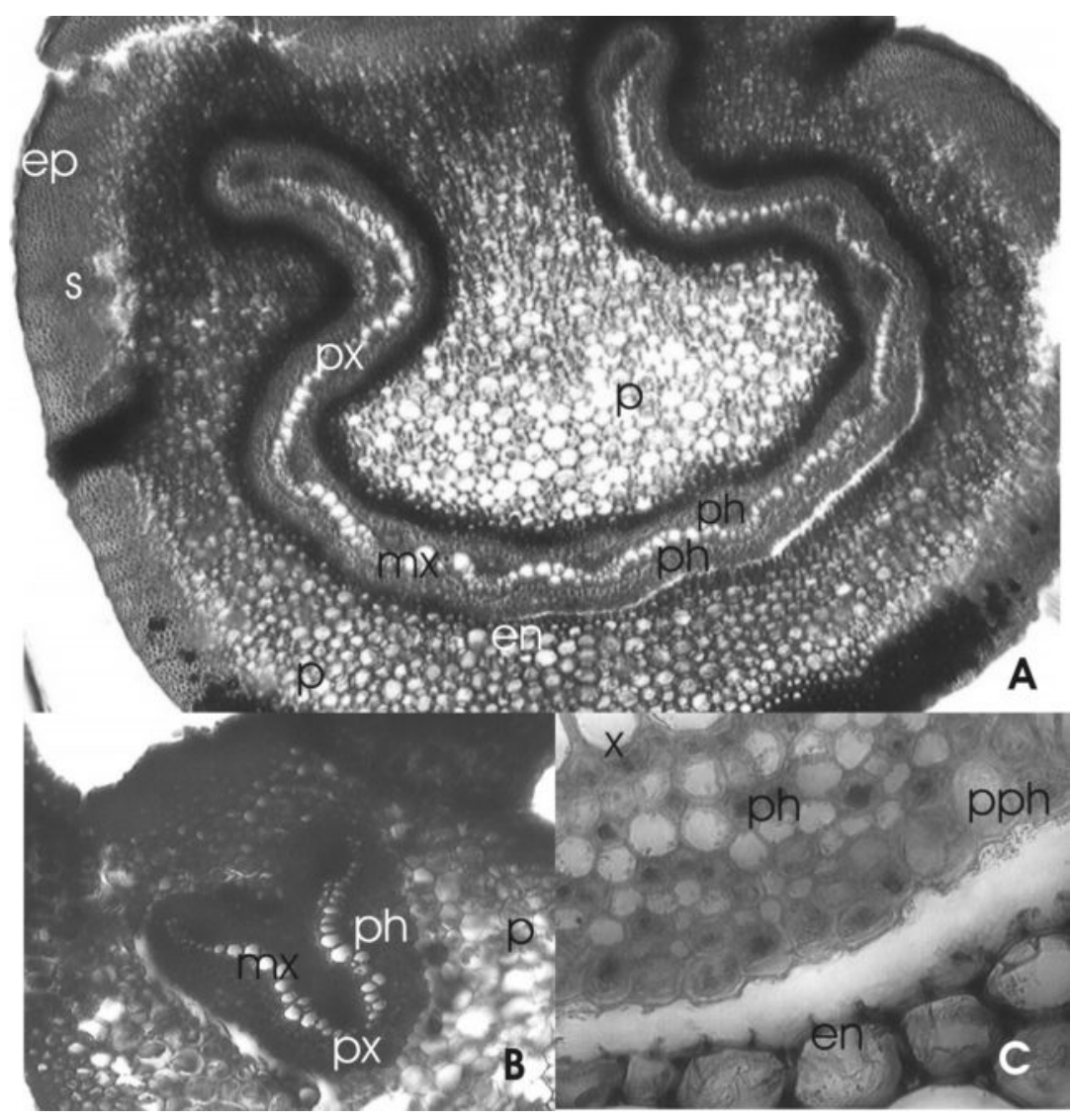

Figure 1. Anatomy of $P$ deflexa fronds. Freehand cut slices were stained with aqueous $1 \%$ tannic acid and $3 \% \mathrm{FeCl}_{3}$ (A) petiole cross section $(40 \mathrm{X})$. The vascular bundle as an inverted $\omega$ shaped arc with ends that curved sharply outwards is observed. The xylem consists of a large circular arc of metaxylem $(\mathrm{mx})$ with some protoxylem $(\mathrm{px})$ at regular intervals. The phloem (ph) encloses the xylem concentrically and is surrounded by an endodermis (en); parenchyma (p), sclerenchyma (s) and epidermis (e) cells are also evident; (B) Rachis branch cross section (100X): It shows the same basic anatomical structure as petiole with minor differences in the vascular bundle form, where the xylem is V-shaped. C) Vascular bundle of petiole cross section (400X): phloem is shaped by sieve tubes (ph) and parenchyma associated to phloem (pph); a xylem vessel $(x)$ and endodermis cells (en) are shown.

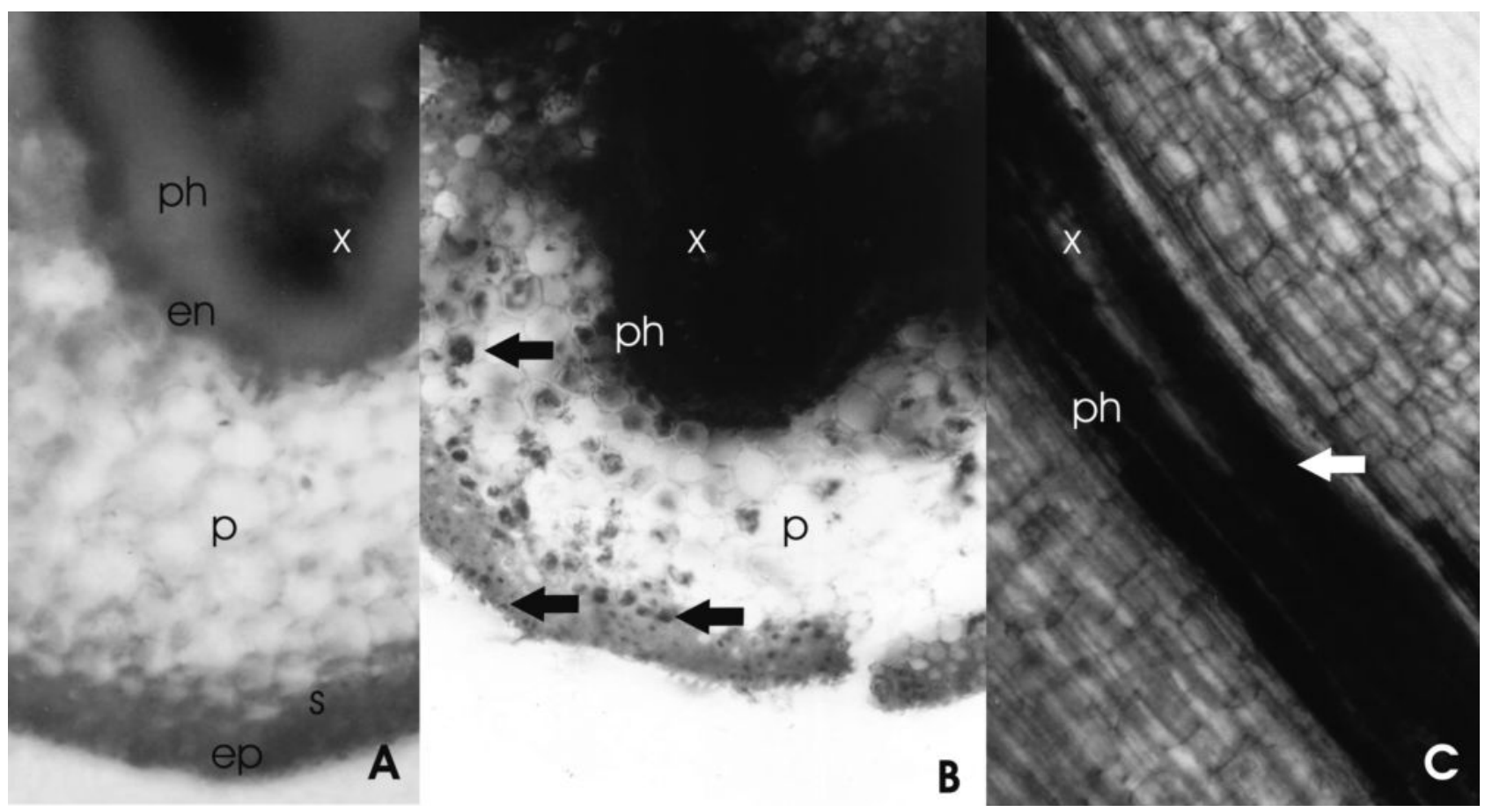

Figure 2. Histochemical detection of acid invertase in frond tissues from $P$. deflexa. (A) Cross section of rachis branch. Negative control incubated without sucrose: xylem $(x)$ and phloem $(\mathrm{ph})$ tissues are observed; an endodermis (en), enclosing the vascular bundle, and parenchyma (p), sclerenchyma (s) and epidermis (ep) are also evident. No enzyme activity signal is observed. (B) Cross section of rachis branch. Acid invertase activity label (arrow), visualized by the deposition of the insoluble blue formazan product, is mainly localized in phloem cells and is also observed in cells of parenchyma, sclerenchyma and epidermis. (C) Longitudinal section of rachis. Acid invertase activity (arrow) is predominantly localized in phloem cells. 


\section{Immunoblot assay}

Western blot and dot blot analysis carried out with soluble or cell wall invertases from $P$. deflexa showed a cross reaction with antibodies developed against acid soluble invertase from $S$. tuberosum (Figure $3 \mathrm{~A}$ and $\mathrm{B}$ ).

\section{Invertase immuno-localization}

Acid invertase immuno-assay with pre-immune serum showed no label on the assayed samples (Figure $4 \mathrm{~A}$ ). Invertase immuno-localization using cross sections of rachis and petioles showed that phloem tissues are clearly labeled (Figure 4 B and C); labeling appeared either in phloem parenchyma or in sieve cells. The enzyme was also present in cortical parenchyma and in sub-epidermal sclerenchyma and epidermis cells (Figure $4 \mathrm{C}$ ). Immunological detection using nitrocellulose tissue prints confirmed the invertase localization observed on fresh tissues (Figure 5) and disclosed that the enzyme was associated to vascular veins in cross sections of lamina.

Two regions were distinguished within the perivascular parenchyma of rachis and petiole: one internal (next to the endodermis) and the other external (next to the sclerenchyma). The first region, yellow coloured in histochemically stained samples, did not show invertase activity; the enzyme was found in the latter, colourless region. Lugol staining of petiole, rachis and thick rachis branches slices established the occurrence of starch granules (not shown) mainly within internal peri-vascular parenchyma cells.

\section{Discussion}

\section{Invertase is present in many frond tissues}

The technique used to the histochemical localization of acid invertase includes a brief tissues fixation in formaldehide $4 \%$ and washing of one hour and reveals glucose, one of the products of the invertase catalized reaction carried out at $\mathrm{pH}$ 6.0. In these conditions is likely that both form of invertase, soluble and cell wall, could be detected. On the other hand, the antibodies used to invertase immunodetection show cross reaction against both cell wall and soluble invertase isoform. Frond invertase isoforms could not be distinguished by the used techniques. Localization studies of the enzyme show that both invertase proteins and activities, were highly coincident in fern tissues. Histochemical and immuno-histochemical studies showed the enzyme predominantly localized in phloem tissues and also in almost every leaf tissue. Invertase immuno-localization carried out on tissue printings, which reveal proteins in their original location, showed the same results as fresh tissue sections.

\section{Phloem invertase}

Invertase detection within the frond vascular tissues is in agreement with the high specific activity of the enzyme found in petiole-rachis and rachis branches of the fern (Sayago et al. 2002). Acid invertase localization in veins of $P$. deflexa agrees with the localization in higher plant tissues like wheat coleoptiles where invertase activity, cell wall and cytoplasmic region, is predominantly localized

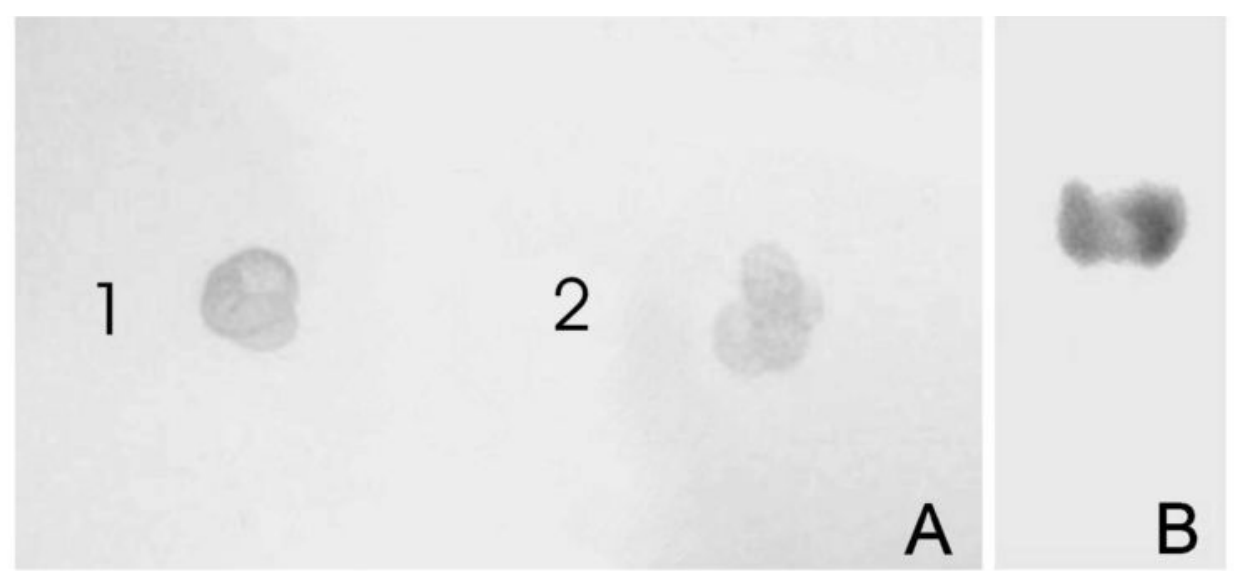

Figure 3. Dot blot (A) and protein gel blot (B) of $P$. deflexa invertase. The cross reaction with the invertase antibody was visualized by NBT/BCIP systems. 1A- soluble acid invertase; 2A cell wall invertase. 1B- soluble acid invertase. 


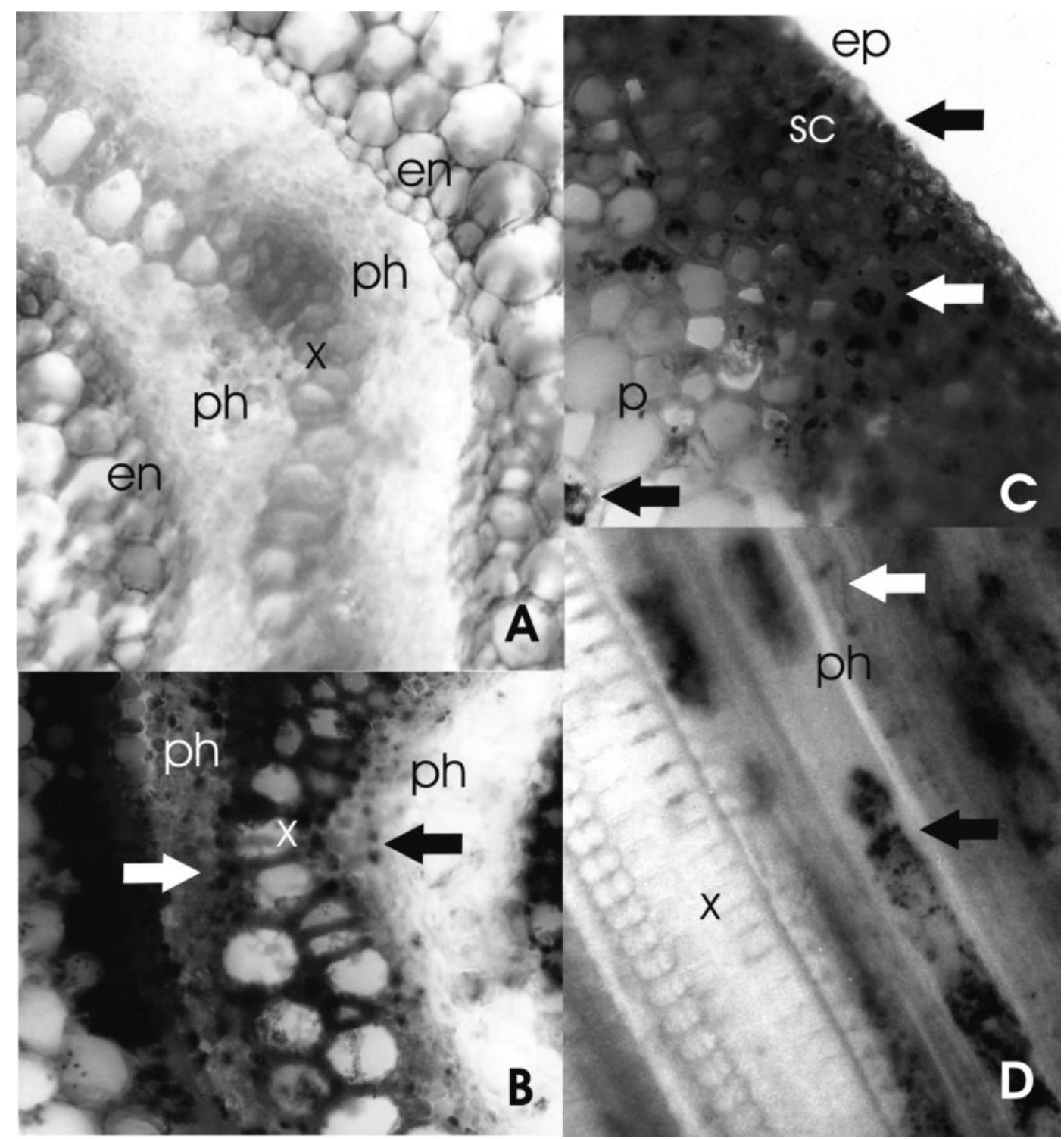

Figure 4. Immuno-localization of invertase in cross (A, B and C) and longitudinal (D) sections of $P$. deflexa petiole. A) Negative control incubated with pre-immune serum. No invertase protein label is detected in xylem (x), phloem (ph) nor endodermis (en) cells. B, C and D) Tissue samples, incubated with antibodies against acid soluble invertase from $S$. tuberosum and with alkaline phosphataseconjugated anti-rabbit IgGs as secondary antibodies, show the signal detection performed using an alkaline phosphatase substrate. Invertase protein (arrow) is visualized in phloem tissues (B and D) as well as in parenchyma, sclerenchyma and epidermis cells (C). Phloem tissues show invertase signal in phloem parenchyma (D, black arrow) as well as in sieve cells (C, white arrow).

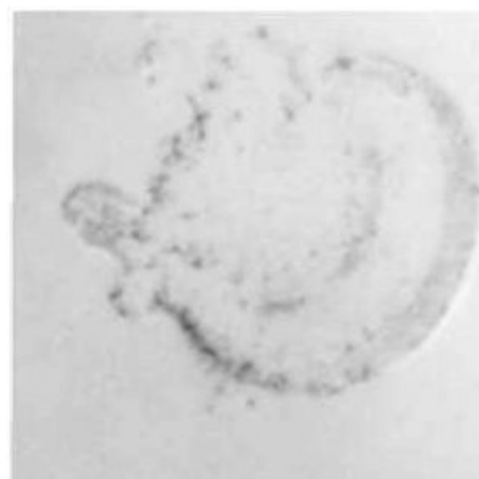

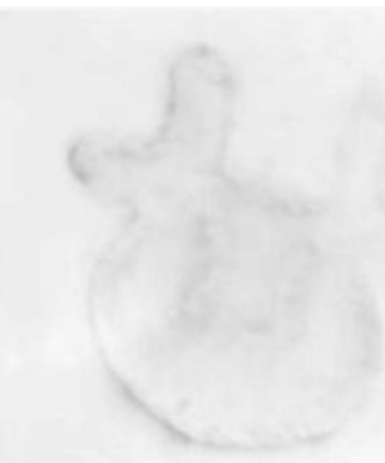

A

Figure 5. Tissue prints of rachis branch of $P$ deflexa fronds. Tissue cross section stained with: (A) Amido black to show total proteins and (B) invertase immunolocalization with antibodies against $S$. tuberosum soluble invertase. 
in vascular tissue cells, whereas lower invertase levels are detected in the cortex (Krishnan et al. 1985). Kingston-Smith and Pollock (1996) using antibodies developed against a 24 aminoacid peptide corresponding to a high homology area of soluble and cell wall invertase, observed a significant enzyme concentration around the veins in barley and pea in contrast with the reduced staining of total proteins in the immunological localization of the enzyme on nitrocellulose tissue prints. Immunocytochemical localization studies in pea revealed high levels of cell-wall invertase in phloem cells (Wu et al. 1993). In agreement with the latter findings, pea cell-wall invertase mRNA localization in phloem tissues was reported by Zhang et al. (1996), who proposed that the physiological significance of cell wall invertase in the phloem could either be the maintenance of a steep sucrose concentration gradient between source and sink regions of a plant, or the provision of hexoses for metabolism in companion cells. Invertase activity in vascular tissues of $P$. deflexa fronds could be involved in phloem unloading and loading, in long distance transport or in phloem unloading similar to the role proposed in higher plants (Kingston-Smith et al. 1999).

\section{Cortex parenchyma as a sink tissue}

Although fronds are autotrophic organs, they have some tissues like epidermis, sclerenchyma and cortical parenchyma of petiole, rachis and rachis branches that are heterotrophic. Thus, occurrence of starch granules in the cortex parenchyma next to the endodermis are not surprising. Among higher plants, the mature Citrus leaf is not generally considered a storage tissue for carbohydrates, but it is known to function as such (Schaffer 1986). Since vascular bundles of petiole, rachis and rachis branches of $P$. deflexa would be symplastically isolated from the cortical parenchyma by the endodermis, cortical parenchyma cells would behave as sink tissue and accumulate photo-assimilates via an apoplastic pathway. In higher plants, cell wall invertase contributes to the development of symplastically isolated sink structures and can also influence sinks in which plasmodesmata are intact (Koch 2004). In developing apple fruits Zhang et al. (2001) demonstrated the symplastic isolation of the sieve element/companion cell complex and suggested that the unloading pathway of sucrose from the complex may occur predominantly via the apoplast, and that the unloaded sucrose may be hydrolyzed by cell wall acid invertase before it is loaded into sink cells. In P. deflexa, invertase activity of the cortical parenchyma of petiole, rachis and rachis branches may produce the post-phloem hydrolysis of sucrose and contribute to the expansion growth of leaves.

\section{Epidermal invertase}

Epidermal cells in higher plants show essentially a heterotrophic tissue sugar profile (Tomos et al. 1992). Epidermal invertase properties of barley are consistent with sucrose hydrolysis being a prerequisite for the storage and metabolism of sugars in such tissue (Obenland et al. 1993). Kingston-Smith et al. (1999) hypothesized that the epidermal isoform of invertase has a significant role in controlling the carbon flux from mesophyll to epidermal cells. In $P$. deflexa fronds, invertase localization is also evident in epidermal cells of petiole, rachis, rachis branches and in frond blade epidermis. Epidermal cells of frond blades are involved not only in the protection of underlying tissues against desiccation but also in producing the sporangia. Consequently, invertase activity in epidermal cells of the sporophyte, like that of the underlying sclerenchyma, could be involved in sugar storage and utilization, while invertase of sporophyll lamina epidermis may also participate in the provision of a carbon source to the cells involved in the formation of sporangia.

\section{Concluding remarks}

In this paper we have described for the first time the localization of acid invertase (vacuolar and cell wall isoforms), a key enzyme of carbohydrate metabolism, in leaf tissues of a lower vascular plant. A close similarity has been established between higher and lower plant invertase localization in leaves. Hence, potential roles of invertase activity in fern leaves could be postulated. However, further studies are required in order to disclose the exact function of these enzymes.

\section{Acknowledgments}

This research was partially supported with grants from the Consejo de Investigación de la Universidad Nacional de Tucumán (CIUNT, Tucumán, Argentina) and from the Consejo Nacional de Investigaciones Científicas y Técnicas (CONICET; Buenos Aires, Argentina). 


\section{References}

Benhamou N, Greiner J, Chrispels M. Accumulation of $\beta$-fructosidase in the cell wall of tomato roots following infection by fungal wilt pathogen. Plant Physiol 1991;97:739-50.

Cheng WH, Taliercio EW, Chourey PS. The Miniature 1 seed locus of maize encodes a cell-wall invertase required for normal development endosperm and maternal cells in pedicel. Plant Cell 1996;8: 971-3.

Dhalqvist A, Brun A. A method for the histochemical demonstration of disaccharidase activities; application to invertase and trehalase in some animal tissues. J Histochem Cytochem 1962;10:294-302.

Eschrich W. Free space invertase, its possible role in phloem unloading. Ber Dtsch Bot Ges 1980;93:363-78.

Feshchenko NF, Krasavina MS, Burmistrova NA, Nosov AV. Phloem unloading and activity of enzymes hydrolyzing sucrose in the apex of the growing root. Doklady Biochem Biophys 2004;399:383-5.

Foster AS. The use of tannic acid and iron chloride for staining cell walls in meristematic tissue. Stain Technol 1934;9:91-2.

Frommer WB, Sonnewald U. Molecular analysis of carbon partitioning in solanaceous species. J Exp Bot 1995;46:587-607.

Isla MI, Vattuone MA, Ordóñez RM, Sampietro AR: Invertase activity associated with walls of Solanum tuberosum tubers. Phytochem 1999, 50: 525-534.

Kingston-Smith $\mathrm{AH}$, Pollock CJ. Tissue level localization of acid invertase in leaves and its potential for the regulation of carbon export. New Phytol 1996;134:423-32.

Kingston-Smith $\mathrm{AH}$, Walker RP, Pollock CJ. Invertase in leaves: conundrum or control point? J Exp Bot 1999;50:735-43.

Koch K. Sucrose metabolism: regulatory mechanisms and pivotal roles in sugar sensing and plant development. Curr Opin Plant Biol 2004; 7:235-46

Krishnan HB, Blanchette JK, Okita TW. Wheat invertases: characterization of cell wall-bound and soluble forms. Plant Physiol 1985;78: 735-43.

McLaughlin JE and Boyer JS. Sugar-responsive gene expression, invertase activity, and senescence in aborting maize ovaries at low water potentials. Ann Bot 2004;94:675-89.

Obenland DM, Simmen V, Boller T, Wiemken A. A Purification and characterization of three soluble invertases from barley (Hordeum vulgare L.) leaves. Plant Physiol 1993;101:1331-9.

Ordóñez RM, Vattuone MA, Isla MI. Changes in carbohydrate content and related enzyme activity during Cyphomandra betaceae (Cav.) Sendtn fruit maturation. Post Biol Technol 2005;35:293-301.

Patrick JW. Phloem unloading: sieve element unloading and post-sieve element transport. Ann Rev Plant Physiol Plant Mol Biol 1997;48: 191-222.

Quick WP, Schaffer AA. Sucrose metabolism in sources and sinks. In
Photoassimilate Distribution in Plants and Crops Source-Sink Relationships Edited by Zamski E, Schaffer AA. New York: Marcel Dekker Inc 1996;115-56.

Sayago JE, Vattuone MA, Sampietro AR, Isla MI. An invertase inhibitory protein from Pteris deflexa Link fronds. J Enz Inhib $2001 ; 16: 517-25$.

Sayago JE, Vattuone MA, Sampietro AR, Isla MI. Proteinaceous inhibitor versus fructose as modulator of Pteris deflexa invertase activity. J Enz Inhib Med Chem 2002;17:123-30.

Schaffer AA. Invertase in young and mature leaves of Citrus sinensis. Phytochem 1986;25:2275-7.

Sergeeva LI, Vreugdenhil D. In situ staining of activities of enzymes involved in carbohydrate metabolism in plant tissues. J Exp Bot 2002;53:361-70.

Sergeeva LI, Keurentjes JJB, Bentsink L, Vonk J, van der Plas LHW, Koornneef $M$. Vacuolar invertases regulates elongation of Arabidopsis thaliana roots as revealed by QTL and mutant analysis. PNAS 2006;103:2994-9.

Sonnewald $U$, Brauer M, Schaewen AV, Stitt M, Willmitzer L. Transgenic tobacco plants expressing yeast-derived invertase in either cytosol, vacuole or protoplast: a powerful tool for studying sucrose metabolism and sink/source interaction. Plant J 1991; 1:95-106.

Sturm A, Sebkova V, Hardegger M, Linehard S, Unger C. Development and organ-specific expression of genes for sucrose synthase and three isoenzymes of acid $\beta$-fructofuranosidase in carrot. Planta 1995; 195:601-10.

Sturm A, Tang G-Q. The sucrose-cleaving enzymes of plants are crucial for development, growth and carbon partitioning. Trends Plant Sci 1999;4:401-7.

Sturm A. Invertases: primary structures, functions, and roles in plant development and sucrose partitioning. Plant Physiol 1999;121:1-7.

Tomos AD, Leigh RA, Palta JA, Williams JHH. Sucrose and cell water relations. In Carbon partitioning within and between organisms. Edited by Pollock CJ, Farrar JF, Gordon AJ. Oxford, Bios Scientific Publishers 1992:71-89.

Tymowska-Lalanne Z, Kreis M. The plant invertases: physiology, biochemistry and molecular biology. Adv Bot Res 1998;28:71-117.

Wu LL, Mitchel JP, Cohn NS, Kaufman PB. Gibberellins (GA3) enhances cell-wall invertase activity and mRNA levels in elongating dwarf pea (Pisum sativum) shoots. Int J Plant Sci 1993;154:2809.

Zhang DP, Lu YM, Wang YZ, Duan CQ, Yan HY. Acid invertase is predominantly localized to cell walls of companion cell complex and parenchyma cells in developing apple fruits. Plant Cell Environ 2001;21:691-702.

Zhang L, Cohn NS, Mitchel JP. Induction of pea cell-wall invertase gene by wounding and its localized expression in phloem. Plant Physiol 1996;110:1111-7. 